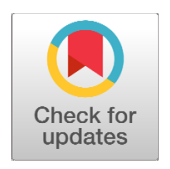

Received: Jul 30, 2021

Revised: Nov 30, 2021

Accepted: Nov 30, 2021

*Corresponding author

Edirisinghe Dewage Nalaka Sandun

Abeyrathne

Department of Animal Science, Uva

Wellassa University, Badulla 90000,

Sri Lanka

Tel: +94-55-2226580

E-mail: sandun@uwu.ac.lk

Copyright (@ 2021 Korean Society of Animal Science and Technology.

This is an Open Access article distributed under the terms of the Creative Commons Attribution Non-Commercial License (http://creati vecommons.org/licenses/by-nc/4.0) which permits unrestricted non-commercial use, distribution, and reproduction in any medium, provided the original work is properly cited.

ORCID

H.M.N.C. Ratnayake https://orcid.org/0000-0001-6285-6072

H.M.J.C. Pitawala

https://orcid.org/0000-0001-8692-5765

E.D.N.S. Abeyrathne

https://orcid.org/0000-0002-6284-2145

\section{Effects of two plant waxes as a coating material on internal attributes of chicken eggs stored under room temperature}

\author{
Herath Mudiyansalage Nuwan Chaminda Ratnayake ${ }^{1}$, \\ Herath Mudiyanselage Jagath Chaminda Pitawala ${ }^{2}$ and \\ Edirisinghe Dewage Nalaka Sandun Abeyrathne ${ }^{1 *}$ \\ ${ }^{1}$ Department of Animal Science, Uva Wellassa University, Badulla 90000, Sri Lanka \\ ${ }^{2}$ Department of Science and Technology, Uva Wellassa University, Badulla 90000, Sri Lanka
}

\begin{abstract}
Surface coatings of eggs are used to extend the shelf life and minimize economic loss. Edible mineral oil is used as a coating material but several problems associated with it and plant waxes are tested as alternatives. "Boomi" (Litsea glutinosa) and "dawul kurundu" (Neolitsea cassia) is found throughout Sri Lanka and barks of these trees are widely used in indigenous medicine due to their antibacterial properties. But, information on these waxes on egg quality attributes does not exist. Objective of this research was to check the effect of "boomi" and "dawul kurundu" waxes as an external coating material on shelf life and internal quality of chicken eggs stored under room temperature. Total of 372 freshly laid brown, medium sized (55-60 g), clean eggs were purchased from a layer farm. Eggs were individually weighed and coated with "boomi" wax (1.0:6.5), "dawul kurundu" wax (01:10) and mineral oil while non coated eggs were used as negative control. Weight loss, change in air sac volume, Haugh unit (HU), yolk color, albumen and yolk pH, yolk index and FTIR analysis were determined at weekly basis for 6 weeks. Albumen and yolk pH increased with storage. But it is significantly lower in mineral coated eggs $(p<0.05)$. Whereas $\mathrm{HU}$ and yolk index decreased during storage in wax coated and non-coated eggs $(p<0.05)$. Grades of non-coated, "boomi" wax coated and "dawul kurundu" wax coated eggs were changed from AA to B within 4 weeks whereas in mineral oil coated eggs (MO) remain in AA. Weight loss of wax coated eggs were significantly higher compared to MOs $(p<0.05)$. FTIR analysis revels that the no chemical changes occur due to the wax. Increase of air sac was higher in noncoated eggs $(5.39 \pm 0.3 \mathrm{~mm})$ after 42 days compared to "boomi" wax (4.59 \pm 0.2 $\mathrm{mm})$, "dawul kurundu" wax $(3.27 \pm 0.3 \mathrm{~mm})$ and mineral oil $(1.19 \pm 0.3 \mathrm{~mm})$ coated eggs. Thus, study showed that these two plant waxes had better qualities than non-coated eggs but less than the MOs.
\end{abstract}

Keywords: Egg coating, Chicken egg, Internal quality, Mineral oil

\section{INTRODUCTION}

Chicken eggs are a predominant complete food which has also the benefit of being inexpensive. They are also rich in vitamins (vitamin $A$, vitamin $B_{6}$, vitamin $D$ ), minerals (selenium) fatty acid (oleic acid, linolenic acid) and proteins (ovalbumin, ovotransferrin, 
Competing interests

No potential conflict of interest

relevant to this article was reported.

Funding sources

Not applicable.

Acknowledgements

Not applicable.

Availability of data and material

Upon reasonable request, the

datasets of this study can be

available from the corresponding

author.

Authors' contributions

Conceptualization: Pitawala HMJC, Abeyrathne EDNS.

Data curation: Rathnayake HMNC, Abeyrathne EDNS.

Formal analysis: Rathnayake HMNC.

Methodology: Pitawala HMJC, Abeyrathne EDNS.

Software: Rathnayake HMNC.

Validation: Pitawala HMJC,

Abeyrathne EDNS.

Investigation: Rathnayake HMNC.

Writing - original draft: Rathnayake HMNC.

Writing - review \& editing: Pitawala HMJC, Abeyrathne EDNS.

Ethics approval and consent to participate

This article does not require IRB/

IACUC approval because there are no human and animal participants. ovomucin) [1]. Due to their multifunctional properties such as foaming, gelling, coagulation and emulsifying they represent an important segment of the world food industry [2]. Global total egg production in 2018 was 76.8 million tons [3] and local total table egg production was 173.7 million in 2019 [4]. However, eggs are highly susceptible to internal quality deterioration and microbial contamination during storage. These conditions can cause serious economic losses to the poultry industry [5].

During storage, higher $\mathrm{pH}$ and thin albumen is caused due to quality changes in albumen and yolk by the fact that moisture and $\mathrm{CO}_{2}$ is loss via the shell pores [6]. Chemical, physical, microbial, and functional properties of eggs start to change as soon as they are laid therefore with the increase of storage time microbial contamination and the susceptibility to internal quality deterioration increase [7]. Shell eggs having a short shelf life (7-10 days) at room temperature. Therefore, preserving eggs becomes important to extend the shelf life of eggs. Among the methods used, low temperature refrigeration is recommended where the shelf life will be extended to five weeks [8]. But, certain barriers such as refrigeration not been available in rural areas and high cost for refrigeration have shown that refrigeration is not a convenient solution for all [9]. As an alternative method, surface coatings can be used to extend shelf life and thus minimize economic loss. In addition to that surface coating on eggs can increase shell strength thus reducing number of cracked eggs [10].

In food industry, edible films and coating play an important role due to its versatile properties such as providing semi-permeable barrier against gases and moisture, reducing respiration, water loss and oxidation reaction rate. Synthetic polymers, polysaccharides and proteins are applied as various coating materials to maintain the shelf life [11]. Currently, mineral oil is used as a coating material. But several problems are associated with the use of mineral oil which include, mineral oil being a petroleum-based product and taking a long time for drying [12]. Therefore, attention has been moved on the use of waxes as coating materials. Waxes are most commonly used hydrophobic film forming barrier material [13]. Different types of waxes such as beeswax, shellac wax, paraffin wax, carnauba wax and candelilla wax are being used. Edible or wax coatings are applied by dipping, brushing, or spraying wax onto the surface of the product. After waxing, a thin layer of wax adheres tightly to the surface, reducing the respiration rate and sealing the moisture of products [14]. Among them, plant waxes are found in common, cheap in price, light in color, non-toxic and biodegradable.

"Boomi" (Litsea glutinosa) is found throughout Sri Lanka. Due to its ayurvedic value, it is used for treatments of diarrhea, dysentery, sprains, bruises, boils and rheumatism [15]. It showed high antibacterial effect Bacillus subtilis, Escherichia coli, and Staphylococcus aureus. The bark mucilage consists of hetero-polysaccharide polyuronides consisting of sugar and uronic acid units which are formed from the cell wall and deposited on it in layers. These polyuronides swell in water and form a gel which is then used as binding agent. Experimentally proven to be a powerful binding agent, the bark mucilage is in formulations for tablets [15].

"Dawul kurundu" (Neolitsea cassia) is a plant native to Sri Lanka. Its leaves are main mucilaginous materials used in traditional culinary practices and it showed characteristic 
cinnamon odor [16]. "Dawul kurundu" had a good swelling index (27.8\%). This mucilaginous material had acidic nature and had acceptable organoleptic properties and micrometric properties. In the method of toddy tapping, the powdered leaf is used to the cut surface of coconut inflorescences [17]. Due to its ayurvedic value, it is used for treatments of fractures and skin rash. It also used for domestic food applications and it is consisted with antioxidant, antibacterial, and anti-inflammatory properties [16]. The weight loss was reduced in great extent by the "dawul kurundu" coating since this micro film act as an additional layer over the leaf surface while covering the stomata holes [18]. There is no information available on the effect of "boomi" tree wax and "dawul kurundu" wax on internal quality and shelf life of eggs during storage. So, the objective was to check the suitability of these two plant waxes as external coating materials on the internal qualities and shelf life of chicken eggs stored at room temperature.

\section{METHODOLOGY}

\section{Materials and methods}

"Boomi" (Litsea glutinosa) wax and "dawul kurundu" (Neolitsea cassia) wax were collected from Teldeniya, Kandy area. Wax solutions were prepared on the day of coating experiment. Unwashed, Clean, brown shell, medium size $(55-60 \mathrm{~g}) 300$ eggs were purchased from layer farm at Demodara area. Coating materials were applied within 24 hours of laying.

\section{Preparation of coating solution and sample preparations}

Pre-trials were conducted to select the best solution from 1:4, 1:6.5, 1:9, and 1:11.5 combination (weight basis) by preparing "Boomi" Wax (BW): distilled water (DW) and 1:5, 1:7.5, 1:10, and 1:12.5 combination (weight basis) by preparing "dawul kurundu" Wax (KW): DW as the coating treatments. "Boomi" wax and "dawul kurundu" wax was weighed with an electric balance (Model: WT200001X, WANT Balance Instrument, Paraguachi, Venezuela). "Boomi" wax was centrifuged (Model: SORV ST 40R) at 1,295 xg for $20 \mathrm{~min}$ and supernatant was separated. Best dilution ratio was selected by observing the thickness of the solution and spreading ability on the egg shell.

Eggs were individually weighed before coating and after coating with a balance. The eggs were coated with mineral oil, "boomi" wax and "dawul kurundu" wax by dipping. Four coating treatments were evaluated throughout the storage period. Negative control (NC) non-coated eggs, positive control (PC)- mineral oil coated eggs (MO), "boomi" wax coated eggs, "dawul kurundu" wax coated eggs. All eggs were placed in a narrow end down position in plastic egg trays and stored at room temperature $\left(27^{\circ} \mathrm{C}\right)$ for 6 weeks. Each egg was considered as one replicate and 72 eggs were coated with same treatment.

\section{Determination of weight loss}

Weight loss of the whole egg during storage was calculated as with the following equation [19]. 
Weight loss $(\%)=\left(\frac{(\text { Intial egg wight }- \text { Weight of the stored egg })}{\text { Intial egg weight }}\right) \times 100$

All the weight was measured in grams. The weight of whole egg was measured with a balance. Three measurements for each treatment taken in weeks intervals.

\section{Determination of Haugh unit, yolk color and egg quality}

Yolk color, Haugh unit (HU) and egg quality was measured by egg analyzer (Model: SN: EA1535 2015). Three measurements per treatment was taken weekly. The yolk width was measured by digital vernier caliper and yolk height was measured by hougher meter. Each value was taken with averaging three different points of yolk. The yolk index was calculated as yolk height/yolk width. Three replicates per treatment was taken weekly.

Albumen and yolk were separated by using egg separator. $\mathrm{pH}$ of the albumin and yolk were obtained suing a pre calibrated digital pH meter (Model: PL 700 pv). Three replicates per treatment was taken weekly basis. Air sac of eggs was identified using an Egg Candler. Then height of the air sac was measured using a Venire caliper. Three measurements per treatment was taken weekly basis.

\section{FTIR ATR analysis of the egg white and yolk}

Fourier Transform Infrared single diamond ATR analysis was done for egg albumen and yolk of all treatments in weekly interval for 6 weeks of storage. Egg albumen and yolk was mixed for $4 \mathrm{~min}$ in a clean beaker using magnet stirrer. A drop of albumen and yolk was placed onto the surface of the ATR diamond crystal and allowed to air dry. Spectra were recorded with a resolution of $2 \mathrm{~cm}^{-1}$, and 32 scans were averaged for each spectrum (scan 4,000-650 $\mathrm{cm}^{-1}$ ). Difference in absorbance unit with the wave number was measured.

\section{Data analysis}

All the data were expressed as means with standard deviation with three replicates. Difference between mean values of three replicates groups were analyzed by one-way analysis of variance (ANOVA) and sensory data were analyzed using Friedman test. Statistical difference was considered at $p<0.05$. Data were analyzing using MINITAB statistical software package and Microsoft office excel software package.

\section{RESULTS AND DISCUSSION}

Effects of mineral oil, and plant waxes on weight loss on eggs stored in room temperature

This is one of the important measurements to monitor the changes in quality of fresh shell eggs during storage. Overall weight loss gradually increased with increased storage periods. Due 
to the loss of water and $\mathrm{CO}_{2}$ from the egg albumen through the shell course the overall weight loss of the whole egg [20]. Eggs coated with mineral oil, "boomi" wax and "dawul kurundu" wax had significantly lesser weight loss than non-coated eggs throughout 6 weeks of storage periods $(p<0.05$; Fig. 1). This study demonstrated that mineral oil and "boomi" wax coatings can offer a protective barrier against the loss of moisture through eggshell, thus reduce weight loss.

Effects of mineral oil and plant waxes on Haugh unit on eggs stored in room temperature

The higher the HU value, the better the albumen quality of eggs [7]. Changes in the HU (used for measurement of the albumen quality) of non-coated and coated eggs are shown in Fig. 2. The initial HU value (75.00) decreased throughout the storage time $(p<0.05)$. Still, this reduces the progressed in much slower rate in eggs coated with mineral oil than for non-coated, "boomi" wax coated and "dawul kurundu" wax coated eggs. Ovomucin proteolysis, cleavage of disulfide bridges, or by the interaction between $\alpha$ and $\beta$ ovomucins may all contribute to a decrease in HU value [21]. Compared with non-coated eggs, eggs coated with "boomi" wax, and "dawul kurundu" wax had significantly higher HU during the storage period at room temperature $(p<0.05)$. According to the HU eggs are divided into 4 grades: AA (> 72), A (72-60), B (59$31)$, and $C(<30)$ [7]. Grades of non-coated and "boomi" wax coated, eggs were changed AA to $\mathrm{B}$ within 4 weeks whereas in $\mathrm{MOs}$ remain in AA.

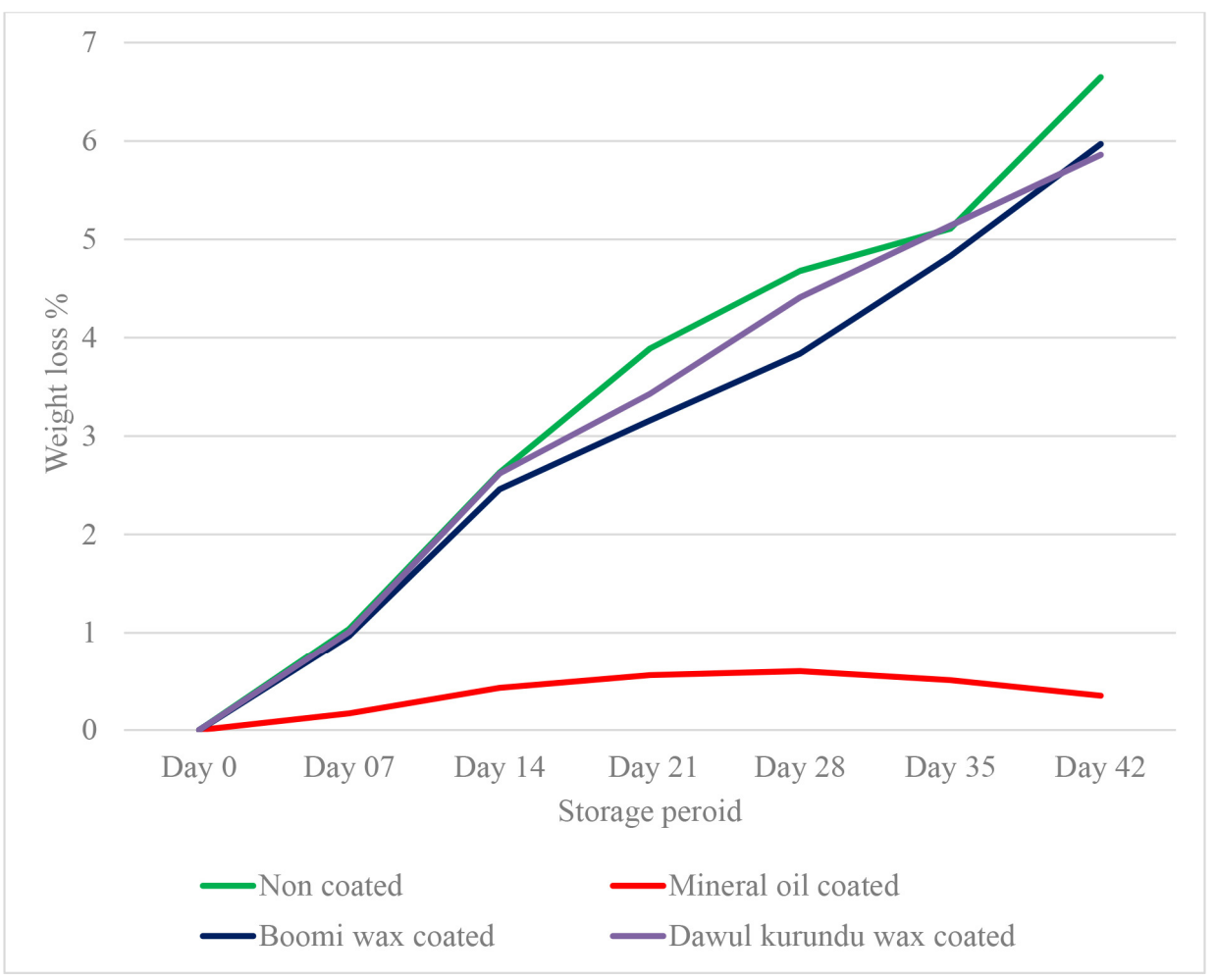

Fig. 1. Changes in the weight loss $(\mathrm{g})$ of coated eggs through the storage period at room temperature. 


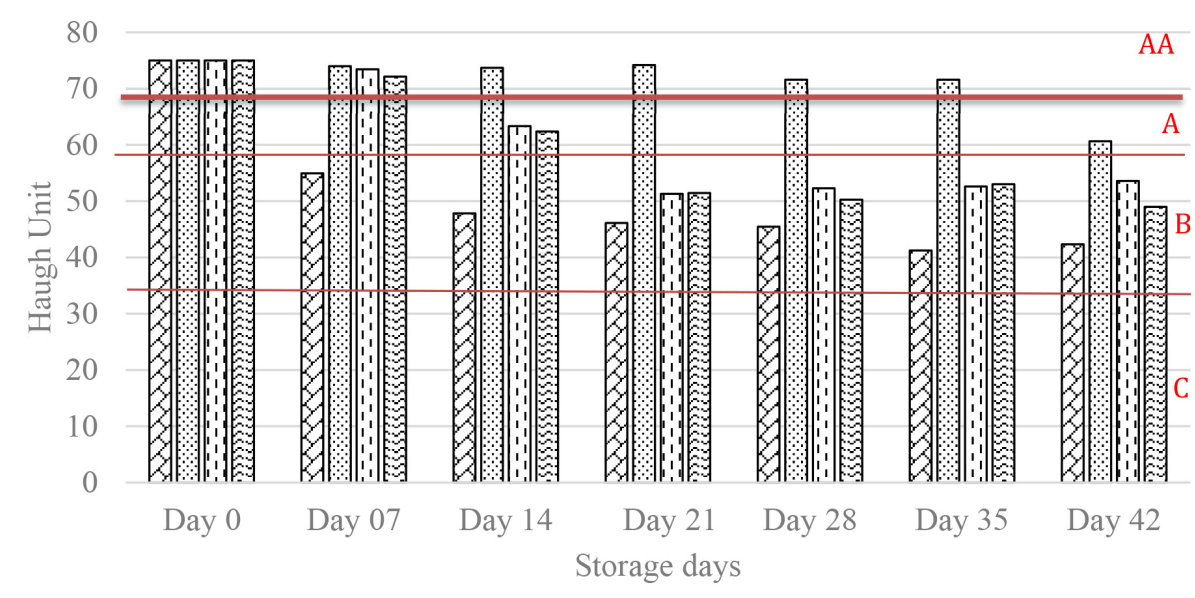

\section{$\square$ Non coated \\ ⿴囗十) Mineral oil coated \\ 四Boomi wax coated \\ 国 Dawul kurundu wax coated}

Fig. 2. Changes in the Haugh unit in coated eggs through the storage period at room temperature. $A A, A$, $B$, and $C$ are the grades of eggs.

Effects of mineral oil and plant waxes on albumen $\mathrm{pH}$ on eggs stored in room temperature

Albumen $\mathrm{pH}$ is also used as an indicator of the quality of eggs egg white [6]. An egg contains of dissolved carbon dioxide $\left(\mathrm{CO}_{2}\right)$ in the carbonate form (albumen) [10]. If the $\mathrm{CO}_{2}$ and moisture in the albumen evaporates through the pores, more air can enter from the shell. Albumen has a $\mathrm{pH}$ of 7.6-8 at first, but when an egg stored in room temperature, $\mathrm{CO}_{2}$ is evaporated through the egg shell pores, increasing the $\mathrm{pH}$ rises to 8.9-9.4. Due to the reduction of $\mathrm{CO}_{2}$ gases, $\mathrm{pH}$ of the egg white increase and structural changes take place in the egg white and result in a thinning of it [22]. Coated eggs had significantly low $\mathrm{pH}$ than uncoated eggs after 7 days of storage $(p<0.05$; Fig. 3$)$. $\mathrm{pH}$ of the albumin primarily measures the freshness of the egg. Accordingly, coating the eggshell reduce the $\mathrm{CO}_{2}$ infusion through the egg shell. Thus, these coatings act as barrier and help to minimize the diffusion of gases through the shell.

Effects of mineral oil and plant waxes on yolk $\mathrm{pH}$ on eggs stored in room temperature

Yolk $\mathrm{pH}$ was also increased by storage time. The yolk $\mathrm{pH}$ in freshly laid eggs is generally about 6.0, but during storage of eggs, the $\mathrm{pH}$ gradually increases to 6.5 [23]. After six weeks of storage initial yolk $\mathrm{pH}$ value (5.98) of noncoated, "boomi" wax, "dawul kurundu" wax and mineral oil were increased to $6.35,6.21,6.71$, and 6.28 respectively. No significant difference was observed in yolk $\mathrm{pH}$ in all treatments up to week $4(p>0.05$; Fig. 4). With the storage, albumen $\mathrm{pH}$ increased due to loosing of $\mathrm{CO}_{2}$ and water from the egg white leading to increased 


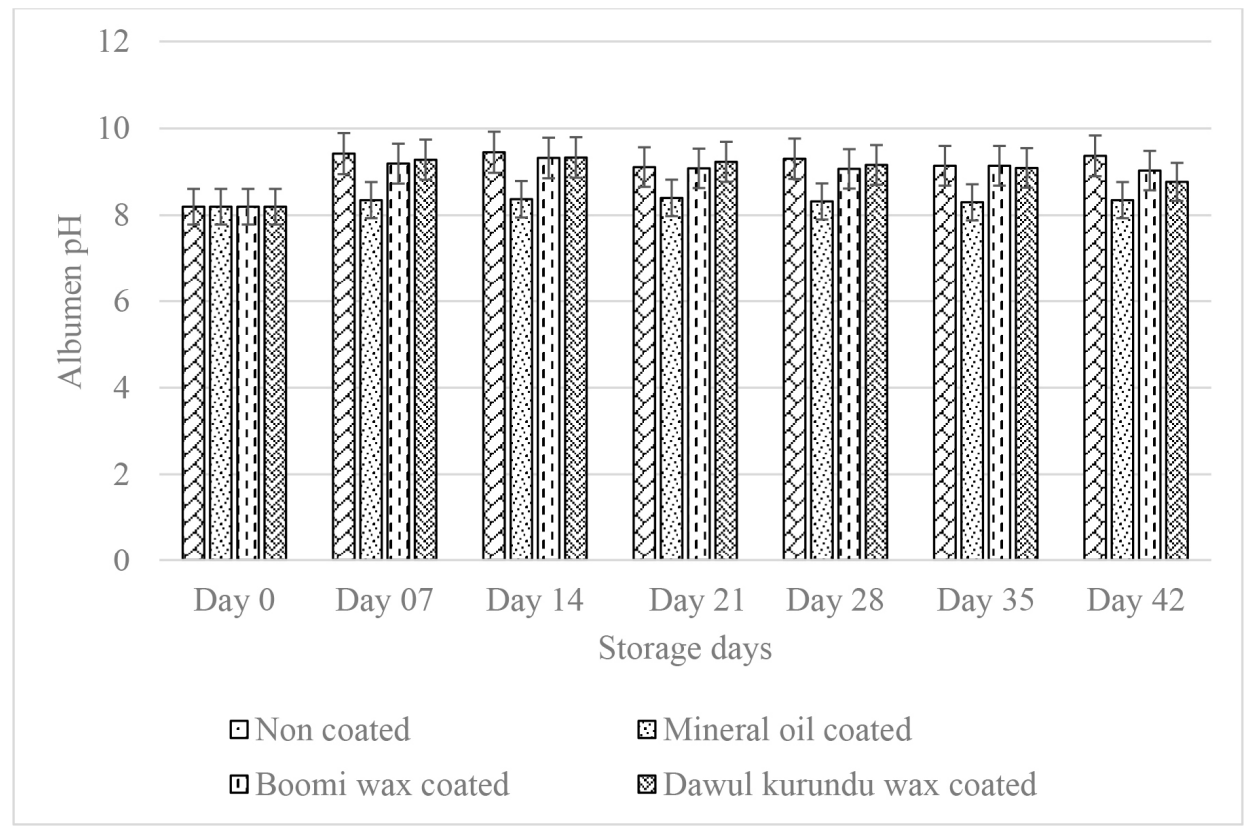

Fig. 3. Changes in the albumin $\mathrm{pH}$ in coated eggs through the storage period at room temperature.

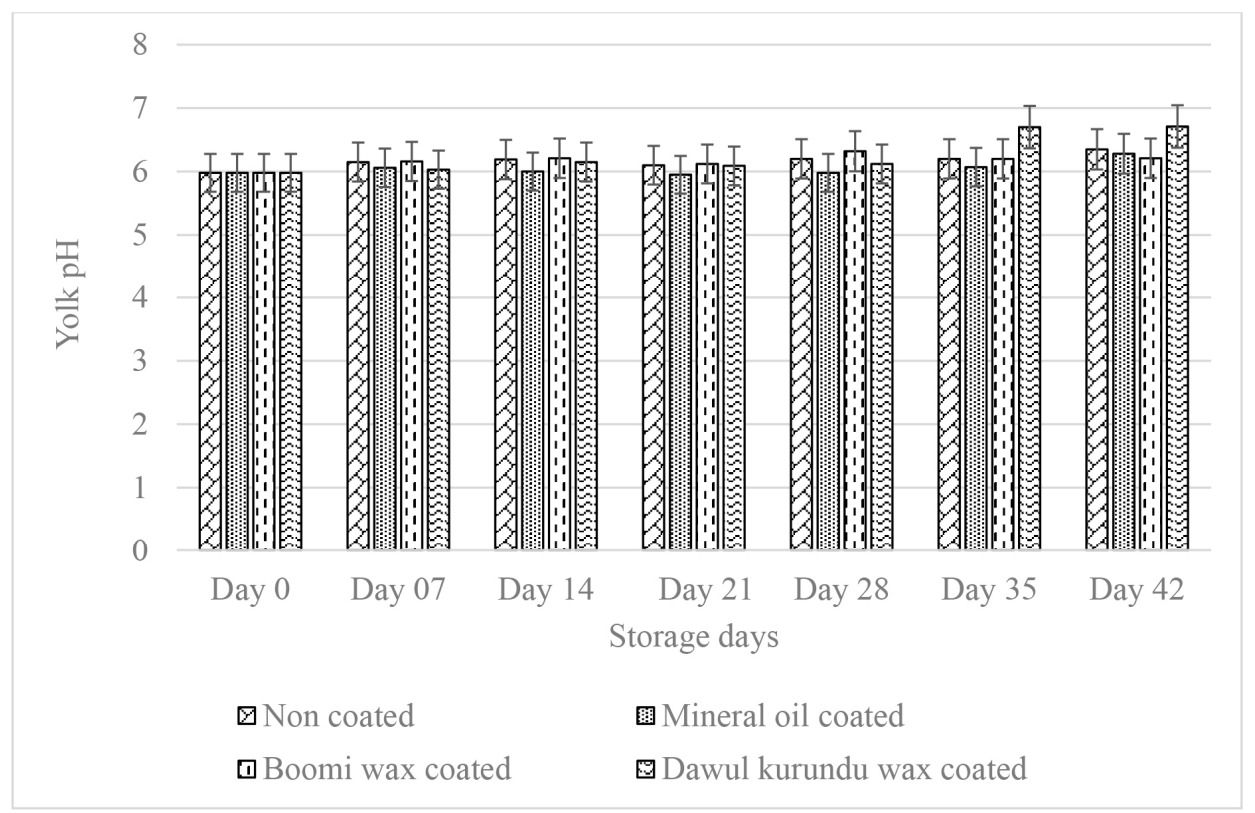

Fig. 4. Changes in the yolk pH in coated eggs through the storage period at room temperature.

$\mathrm{pH}$ of the yolk as well [10]. Accordingly, coating of the eggshell declines $\mathrm{CO}_{2}$ infusion. The coatings act as barrier and help diffuse gases less rapidly through the shell.

Effects of mineral oil and plant waxes on yolk index on eggs stored in room temperature

With storage times, the yolk index values generally decreased. Yolk index reduce as a result 
of a with the weakening of the vitelline membrane, reducing the total solid and liquefaction of the yolk mainly caused by the osmotic diffusion of water from the egg white [6]. Yolk index of non-coated and coated eggs reduced significantly $(p<0.05)$ with increased storage periods. After storing eggs for six weeks, initial yolk index value (0.44) of noncoated, “boomi” wax, "dawul kurundu" wax and mineral oil were decreased to 0.18, 0.22, 0.22, and 0.39 respectively (Fig. 5). These results indicated that, mineral oil coating has enhancement effect in maintaining yolk quality during storage.

\section{Effects of mineral oil on air sac volume on eggs stored in room temperature}

The air cell is situated at the blunt end between the shell membrane and the egg membrane. The egg shell is more porous at this end and therefore air will enter here as the egg contents shrink due to cooling down after laying. During storage the air cell gradually increases in sizes as water evaporates from the egg contents [24]. In this study, the air cell height of all eggs increased with increased storage time during 6 weeks at room temperature (Table 1). After 6 weeks of storage, all coated eggs had significantly $(p<0.05)$ lesser air cell height than non-coated eggs.

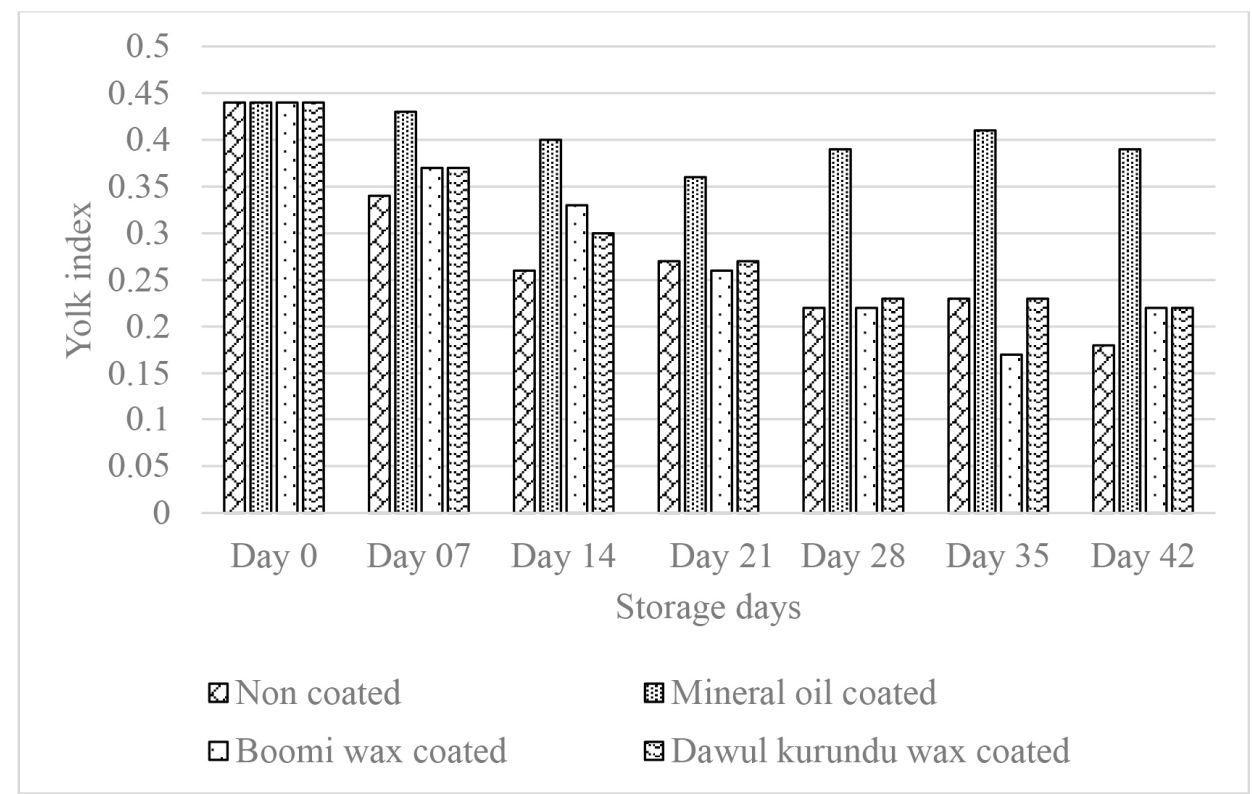

Fig. 5. Changes in the yolk index through the storage period at room temperature.

Table 1. Changes in the air sac volume $(\mathrm{mm})$ of coated eggs during 42 days of storage at room temperature

\begin{tabular}{lcccccc}
\hline Storage periods & Day 0 & Day 14 & Day 21 & Day 28 & Day 35 \\
\hline Non coated & $0.76 \pm 0.05$ & $1.12 \pm 0.02$ & $1.90 \pm 0.08$ & $2.10 \pm 0.1$ & $3.35 \pm 0.2$ & $5.39 \pm 0.3$ \\
Mineral oil & $0.76 \pm 0.05$ & $1.04 \pm 0.3$ & $1.08 \pm 0.3$ & $1.15 \pm 0.08$ & $1.12 \pm 0.08$ & $1.19 \pm 0.2$ \\
"Boomi" wax coated & $0.76 \pm 0.05$ & $1.76 \pm 0.03$ & $1.99 \pm 0.1$ & $2.12 \pm 0.1$ & $3.01 \pm 0.1$ & $4.59 \pm 0.2$ \\
"Dawul kurundu" wax coated & $0.76 \pm 0.05$ & $1.30 \pm 0.05$ & $1.44 \pm 0.1$ & $2.20 \pm 0.1$ & $3.26 \pm 0.1$ & $3.27 \pm 0.3$ \\
\hline
\end{tabular}


FTIR ATR analysis of the egg white and yolk coated with mineral oil, "Boomi" wax and "Dawul Kurundu" wax stored under room temperature

Albumin is a class of simple, water-soluble proteins that are found in egg white. Albumin is known to have a secondary structure that includes alpha-helices, parallel beta sheets, antiparallel beta sheets, and random coils. The secondary structure of albumin is sensitive to environmental changes, including changes in $\mathrm{pH}$. Addition of an acid or a base to an albumin solution changes the number and the distribution of the charges on the protein [25]. In the yolk spectrum, bands seemed at the 2,900 and 2,850 $\mathrm{cm}^{-1}$ can be related to the widening vibrations of the $\mathrm{C}-\mathrm{H}$ group in lipid molecules. The band appaired at the region of $1,750 \mathrm{~cm}^{-1}$ can be linked with widening vibrations of the $\mathrm{C}=\mathrm{O}$ group of saturated aliphatic esters. In the areas of 1,650 and 1,550 $\mathrm{cm}^{-1}$, there are two amides' bands (respectively: amide I and II) associated with vibrations of peptide bonds of proteins [26]. Through the storage period (6 weeks), there was no significant difference in absorption units in-between $1,600-1,700 \mathrm{~cm}^{-1}$ wave numbers in all coated and non-coated eggs (Fig. 6). Thus, there were no significant difference $(p<0.05)$ in secondary structure of egg protein reveals that no chemical structure changes occur due to the application of these coating materials.

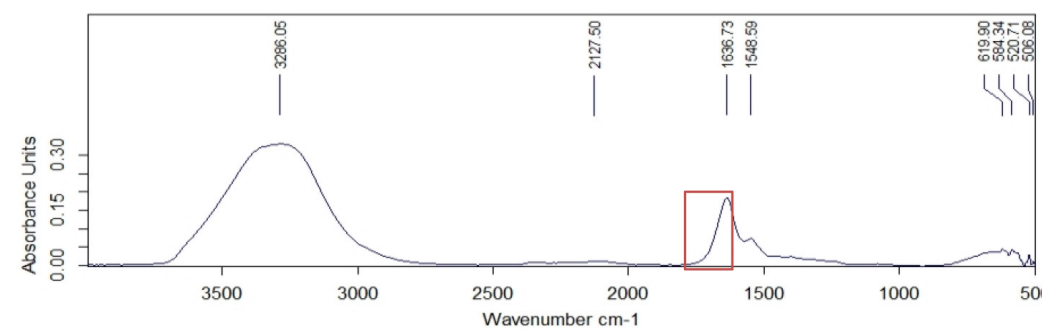

Day 0 all eggs
FTIR spectrum

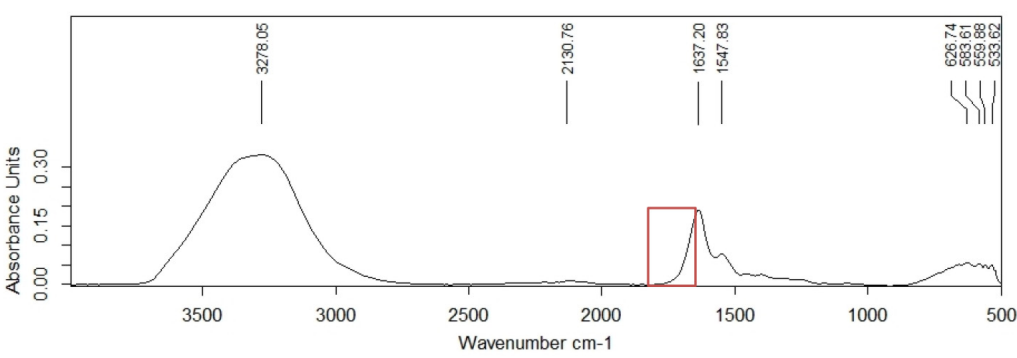
Day 42 non
coated eggs

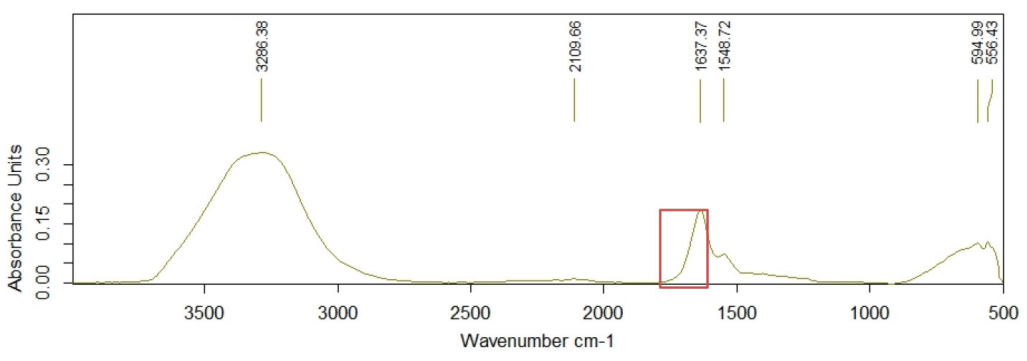

Day 42 mineral oil coated eggs

Fig. 6. FIIR spectrums of non-coated, mineral oil, "boomi" wax and "dawul kurundu" wax coated eggs at $42^{\text {nd }}$ day of storage time. 


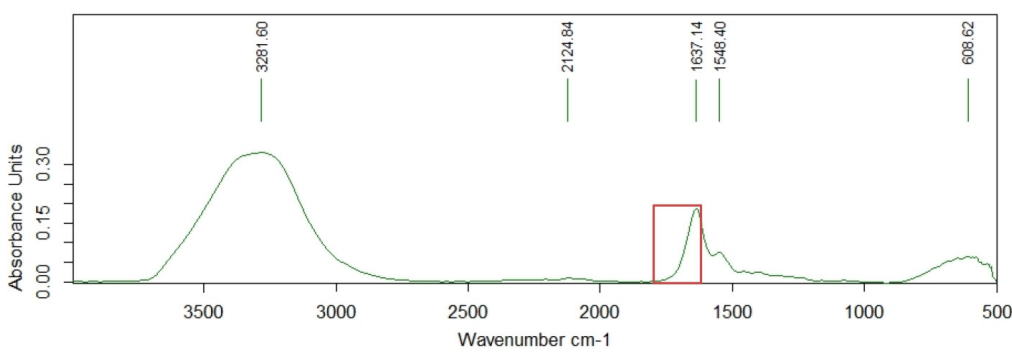

Day 42 "boomi" wax coated eggs

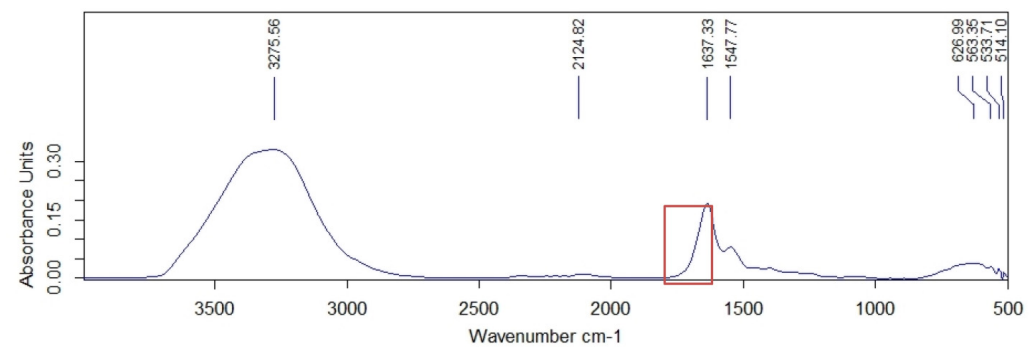

Day 42 " dawul kurundu" coated eggs

Fig. 6. Continued

\section{CONCLUSION}

"Boomi wax" coated eggs and "Dawul kurundu" coated eggs show better internal quality parameters than non-coated eggs but not more than MOs. Therefore, these two plant waxes have the potential in using as a coating material but it is less effective than the mineral oil.

\section{REFERENCES}

1. Abeyrathne EDNS, Huang X, Ahn DU. Antioxidant, angiotensin-converting enzyme inhibitory activity and other functional properties of egg white proteins and their derived peptides: a review. Poult Sci. 2018;97:1462-68. https://doi.org/10.3382/ps/pex399

2. Liu YF, Oey I, Bremer P, Carne A, Silcock P. Modifying the functional properties of egg proteins using novel processing techniques: a review. Compr Rev Food Sci Food Saf. 2019;18:986-1002. https://doi.org/10.1111/1541-4337.12464

3. Molnár S, Szőllősi L. Sustainability and quality aspects of different table egg production systems: a literature review. Sustainability. 2020;12:7884. https://doi.org/10.3390/su12197884

4. Department of Census and Statistics. National livestock statistics 2015-2020 [Internet]. Colombo, Sri Lanka: Department of Census and Statistics. 2021 [cited 2021 Jul 8]. http://www.statistics.gov.lk/Agriculture/Staticallnformation/rubb4

5. Wong YC, Herald TJ, Hachmeister KA. Evaluation of mechanical and barrier properties of protein coatings on shell eggs. Poult Sci. 1996;75:417-22. https://doi.org/10.3382/ps.0750417

6. Nongtaodum S, Jangchud A, Jangchud K, Dhamvithee P, No HK, Prinyawiwatkul W. Oil coating affects internal quality and sensory acceptance of selected attributes of raw eggs during storage. J Food Sci. 2013;78:S329-35. https://doi.org/10.1111/1750-3841.12035

7. Mudannayaka AI, Rajapaksha DSW, Kodithuwakku KAHT. Effect of beeswax, gelatin and 
aloe vera gel coatings on physical properties and shelf life of chicken eggs stored at $30^{\circ} \mathrm{C}$. J World Poult Res. 2016;6:6-13.

8. Akter Y, Kasim A, Omar H, Sazili AQ. Effect of storage time and temperature on the quality characteristics of chicken eggs. J Food Agric Environ. 2014;12:87-92.

9. Jirawatjunya J. Effects of assorted coating materials and room temperature storage on internal quality and oxidative stability of shell eggs [M.S. thesis]. Baton Rouge, Louisiana: Louisiana State University; 2013.

10. Biladeau AM, Keener KM. The effects of edible coatings on chicken egg quality under refrigerated storage. Poult Sci. 2009;88:1266-74. https://doi.org/10.3382/ps.2008-00295

11. Caner C. Whey protein isolate coating and concentration effects on egg shelf life. J Sci Food Agric. 2005;85:2143-48. https://doi.org/10.1002/jsfa.2225

12. Torrico DD. Effects of emulsion coatings on the internal quality and shelf life of eggs. [M.S. thesis]. Baton Rouge, Louisiana: Louisiana State University; 2010.

13. Edirisinghe EDMT, Jayasinghe JMP, Himali SMC, Abeyrathne EDNS. Effect of beeswax and gammalu (Pterocarpus marsupium) latex coating on internal and sensory attributes of chicken eggs stored at room temperature. Int J Res Agric Sci. 2017;4:2348-3997.

14. Vakkalanka MS, D’Souza T, Ray S, Yam KL, Mir N. Emerging packaging technologies for fresh produce. In: Yam KL, Lee DS, editors. Emerging food packaging technologies. Woodhead, Cambridge, UK; 2012. p. 109-33.

15. Ramana KV, Raju AS. Traditional and commercial uses of Litsea glutinosa (Lour.) CB Robinson (Lauraceae). J Med Plants Stud. 2017;5:89-91.

16. Kasunmala IGG, Navarathne SB, Wickramasinghe I. extraction and characterization of mucilaginous material from Dawul kurundu leaves (Neolitsea involucrate) and Godapara fruits (Dillenia retusa). Int J Food Sci Nutr. 2017.

17. de Silva SSM, Kumar NS, Åman P. Structural studies of an arabinoxylan isolated from the leaves of Neolitsea cassia. Carbohydr Res. 1986;152:229-36. https://doi.org/10.1016/S0008-62 15(00)90302-1

18. Wijerathne PAKC, Chandrajith VGG, Navaratne SB. Controlling of post-harvest losses of selected leafy vegetables and green chilies by coating with plant mucilages. Agric Res Technol. 2018. https://doi.org/10.19080/ARTOAJ.2018.16.556005

19. Waimaleongora-Ek P, Garcia KM, No HK, Prinyawiwatkul W, Ingram DR. Selected quality and shelf life of eggs coated with mineral oil with different viscosities. J Food Sci. 2009;74:S423-29. https://doi.org/10.1111/j.1750-3841.2009.01341.x

20. Pires PGS, Machado GS, Franceschi CH, Kindlein L, Andretta I. Rice protein coating in extending the shelf-life of conventional eggs. Poult Sci. 2019;98:1918-24. https://doi.org/10. $3382 / \mathrm{ps} / \mathrm{pey} 501$

21. Junior JAQL, de Oliveira MJ, de Oliveira DRB, Santos IJB, Saldaña MDA, dos Reis Coimbra JS. Emulsifying properties of quail egg white proteins in different vegetable oil emulsions. Acta Sci Technol. 2021;43:e50067. https://doi.org/10.4025/actascitechnol.v43i1.50067

22. Pires PGS, Leuven AFR, Franceschi CH, Machado GS, Pires PDS, Moraes PDO, et al. 
Effects of rice protein coating enriched with essential oils on internal quality and shelf life of eggs during room temperature storage. Poult Sci. 2020;99:604-11. https://doi.org/10.1111/ 1750-3841.12035

23. Caner C, Yüceer M. Efficacy of various protein-based coating on enhancing the shelf life of fresh eggs during storage. Poult Sci. 2015;94:1665-77. https://doi.org/10.3382/ps/pev102

24. Samli HE, Agma A, Senkoylu N. Effects of storage time and temperature on egg quality in old laying hens. J Appl Poult Res. 2005;14:548-53. https://doi.org/10.1093/japr/14.3.548

25. Kudryashova EV, Visser AJWG, De Jongh HHJ. Reversible self-association of ovalbumin at air-water interfaces and the consequences for the exerted surface pressure. Protein Sci. 2005;14:483-93. https://doi.org/10.1110/ps.04771605

26. Michalczyk E, Kurczab R. Assessment of poultry eggs freshness using FTIR spectroscopy combined with HCA and PCA methods. Sci Technol Innov. 2018;2:7-12. https://doi.org/ 10.5604/01.3001.0012.1414 